\title{
First record of Psallus assimilis in Hungary (Hemiptera: Heteroptera: Miridae)
}

\author{
D. KORÁNYI ${ }^{1}$, V. MARKÓ ${ }^{2}$, E. KONDOROSY ${ }^{1}$ \\ ${ }^{1}$ Dávid Korányi \& Elöd Kondorosy, Department of Animal Science, Georgikon Faculty, University \\ of Pannonia, H-8361 Keszthely, Deák Ferenc utca 16, Hungary \\ E-mails: koranyi@georgikon.hu, kondorosy@georgikon.hu \\ ${ }^{2}$ Viktor Markó, Department of Entomology, Faculty of Horticultural Science, Szent István University, \\ H-1118 Budapest, Villányi út 29-43, Hungary.E-mail: marko.viktor@kertk.szie.hu
}

\begin{abstract}
The presence of Psallus assimilis Stichel, 1956 (Hemiptera: Heteroptera: Miridae) is reported for the first time from Hungary. Specimens were collected from the canopy of field maple (Acer campestre L.) trees in Budapest, Diósd and Törökbálint in spring of 2015, 2016 and 2017. Our study indicates that $P$. assimilis is one of the most abundant heteropteran species in the canopy of field maple trees not only in suburban and urban forests but also on individual street trees in highly urbanized locations in Budapest. We provide photographs of the habitus and diagnostic characters of adults.
\end{abstract}

Keywords. Heteroptera, Acer campestre, urban areas, distribution, faunistics.

\section{INTRODUCTION}

Psallus Fieber, 1858 is one of the largest genera of Miridae (Hemiptera: Heteroptera); it comprises almost 140 species in the Palearctic Region (Kerzhner \& Josifov 1999, Aukema et al. 2013), 23 of which have also been recorded from Hungary. Eleven of these species, e.g. P. anaemicus, $P$. helenae and $P$. pardalis, were recorded during the last twenty-five years (Kondorosy 1999, 2005, 2011, 2012).

Psallus species are primarily zoophytophagous in the adult stage. Young nymphs feed on pollen, therefore they can only be found on mature, fertile host plants. Later nymphal stages become predatory, and prey mainly on mites and aphids, but also on other insects, e.g. scale insects, psyllids and caterpillars (Wachmann et al. 2004), or eggs of leaf beetles (Björkman et al. 2009). Many species of this genus are associated with oak trees (Quercus spp.), while other species are found on other deciduous and coniferous trees and shrubs (e.g. Picea, Larix, Fraxinus and Fagus spp.) (Wachmann et al. 2004, Goßner 2008).

\section{MATERIAL AND METHODS}

The arthropod community in the canopies of field maple (Acer campestre L.) trees was surveyed in 23 locations of Budapest, Hungary: Alkotás utca $\left(47^{\circ} 29^{\prime} 22.6^{\prime \prime} \mathrm{N}, 1^{\circ} 01^{\prime} 27.6^{\prime \prime} \mathrm{E}, 142 \mathrm{~m}\right.$ a.s.l.), Botanical Garden Buda $\left(47^{\circ} 28^{\prime} 49.4^{\prime \prime} \mathrm{N}\right.$, $19^{\circ} 02^{\prime} 12.6^{\prime \prime E}, 113 \mathrm{~m}$ a.s.l.), Csillebérc (47²9' 25.1"N, 18 ${ }^{\circ} 7^{\prime} 39.4^{\prime \prime E}, 447 \mathrm{~m}$ a.s.1.), Farkasvölgy $\left(47^{\circ} 29^{\prime} 05.0^{\prime \prime} \mathrm{N}, 18^{\circ} 59^{\prime} 09.4^{\prime \prime} \mathrm{E}, 304 \mathrm{~m}\right.$ a.s.l.), Gellért-hegy $\left(47^{\circ} 29^{\prime} 09.3^{\prime \prime} \mathrm{N}, 1^{\circ} 02^{\prime} 51.1^{\prime \prime} \mathrm{E}, 187 \mathrm{~m}\right.$ a.s.l.), Haller park $\left(47^{\circ} 28^{\prime} 28.5^{\prime \prime} \mathrm{N}, 19^{\circ} 04^{\prime} 49.0^{\prime \prime} \mathrm{E}\right.$, $107 \mathrm{~m}$ a.s.1.), Hegyalja út $\left(47^{\circ} 29^{\prime} 07.7^{\prime \prime} \mathrm{N}, 19^{\circ} 01^{\prime}\right.$ $00.3^{\prime \prime E}, 193 \mathrm{~m}$ a.s.l.), Hunyadi tér $\left(47^{\circ} 30^{\prime} 21.3^{\prime \prime} \mathrm{N}\right.$, $19^{\circ} 04^{\prime} 00.2^{\prime \prime E}, 104 \mathrm{~m}$ a.s.l.), Hủvösvölgy $\left(47^{\circ} 32^{\prime}\right.$ $30.7^{\prime \prime} \mathrm{N}, 18^{\circ} 57^{\prime} 49.5^{\prime \prime} \mathrm{E}, 227 \mathrm{~m}$ a.s.l.), Karolina út $\left(47^{\circ} 28^{\prime} 45.6^{\prime \prime} \mathrm{N}, 19^{\circ} 01^{\prime} 53.5^{\prime \prime} \mathrm{E}, 110 \mathrm{~m}\right.$ a.s.l.), Keleti Pályaudvar $\left(47^{\circ} 29^{\prime} 59.3^{\prime \prime} \mathrm{N}, 19^{\circ} 05^{\prime} 03.1 " \mathrm{E}, 109 \mathrm{~m}\right.$ a.s.1.), Ludovika tér $\left(47^{\circ} 28^{\prime} 55.1^{\prime \prime} \mathrm{N}, 19^{\circ} 05^{\prime} 01.6^{\prime \prime} \mathrm{E}\right.$, $110 \mathrm{~m}$ a.s.1.), Margit-sziget $\left(47^{\circ} 31^{\prime} 24.9^{\prime \prime} \mathrm{N}, 19^{\circ} 02^{\prime}\right.$ 9.8"E, $104 \mathrm{~m}$ a.s.1.), Mátyás tér $\left(47^{\circ} 29^{\prime} 31.6^{\prime \prime} \mathrm{N}\right.$, $19^{\circ} 04^{\prime} 45.3^{\prime \prime E}, 105 \mathrm{~m}$ a.s.1.), Normafa $\left(47^{\circ} 30^{\prime}\right.$ 24.1"N, 18 ${ }^{\circ} 57^{\prime} 42.5^{\prime \prime} \mathrm{E}, 460 \mathrm{~m}$ a.s.l.), Rácz Aladár út $\left(47^{\circ} 28^{\prime} 59.2^{\prime \prime} \mathrm{N}, 18^{\circ} 59^{\prime} 43.9^{\prime \prime} \mathrm{E}, 253 \mathrm{~m}\right.$ a.s.1.), Rákóczi tér $\left(47^{\circ} 29^{\prime} 33.8^{\prime \prime} \mathrm{N}, 19^{\circ} 04^{\prime} 19.8^{\prime \prime} \mathrm{E}, 104 \mathrm{~m}\right.$ 
a.s.1.), Róbert Károly körút $\left(47^{\circ} 32^{\prime} 08.5^{\prime \prime} \mathrm{N}, 19^{\circ} 03^{\prime}\right.$ 47.4"E, $107 \mathrm{~m}$ a.s.1.), Szent István park (47³1' 07.6"N, 1903'03.9"E, $105 \mathrm{~m}$ a.s.l.), Széchenyihegy $\left(47^{\circ} 29^{\prime} 42.4^{\prime \prime} \mathrm{N}, 18^{\circ} 58^{\prime} 30.5^{\prime \prime} \mathrm{E}, 461 \mathrm{~m}\right.$ a.s.l.), Városmajor $\left(47^{\circ} 30^{\prime} 30.6^{\prime \prime} \mathrm{N}, 19^{\circ} 01^{\prime} 02.2^{\prime \prime} \mathrm{E}, 135 \mathrm{~m}\right.$ a.s.1.), Vérmező $\left(47^{\circ} 30^{\prime} 05.0^{\prime \prime} \mathrm{N}, 1^{\circ} 01^{\prime} 31.7^{\prime \prime} \mathrm{E}\right.$, $125 \mathrm{~m}$ a.s.1.), Zugligeti út $\left(47^{\circ} 31^{\prime} 03.9^{\prime \prime} \mathrm{N}, 18^{\circ} 59^{\prime}\right.$ 09.3"E, $180 \mathrm{~m}$ a.s.1.) and in Diósd $\left(47^{\circ} 24^{\prime} 44.2^{\prime \prime} \mathrm{N}\right.$, $18^{\circ} 56^{\prime} 17.5^{\prime \prime E}, 165 \mathrm{~m}$ a.s.l.) and Törökbálint (470 $25^{\prime} 58.2^{\prime \prime} \mathrm{N}, 18^{\circ} 55^{\prime} 37.0^{\prime \prime} \mathrm{E}, 182 \mathrm{~m}$ a.s.1.).

Tree canopies were sampled monthly from April to October in 2015, 2016 and 2017. Arthropods were collected by beating the branches of each sampled field maple trees over beating umbrella. Samples were stored in $70 \%$ ethanol, heteropterans were examined in the laboratory of the Department of Entomology of Szent István University (SZIU). Adults of Psallus species were identified by D. Korányi using characters of the exoskeleton and male genitalia following the keys of Wagner (1967) and Wyniger (2004). Photographs of habitus and femora (Fig. 1) were taken using a Sony XCD-SX90CR digital interface connected to a Zeiss Stemi 2000 stereomicroscope, those of the vesica (Fig. 2) using a Zeiss Imager A2 light microscope equipped with Axio Cam MRc5.

\section{RESULTS}

Among the 5536 heteropteran individuals collected during the study, 714 specimens (226 $\widehat{\partial} \widehat{\partial}$, 488 우) were identified as $P$. assimilis. Further

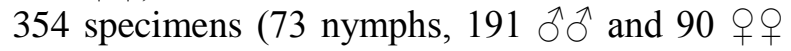
damaged or teneral adults) of Psallus spp. were very similar to $P$. assimilis and likely represented this species, but they could not be unambiguously identified to species level. Collected specimens were deposited in the Hemiptera Collection of the Hungarian Natural History Museum (HNHM) and the insect collection of Department of Entomology, SZIU.

Material examined. Alkotás utca, 7.v.2015, 27

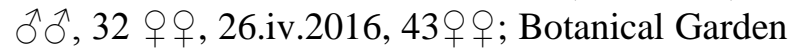
Buda, 7.v.2015, 13 ๙ิ๋, 25 우, 26.iv.2016, 35 우; Csillebérc, 25.v.2016, 8 ठํ, 5 우우, 22.vi.2016, 1 ; Diósd, 25.v.2016, 1 §, 2 우;

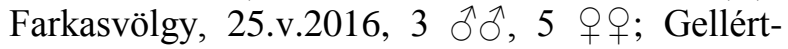
hegy, 7.v.2015, 79 ๙ึ่, 91 우, 26.iv.2016, 1 q, 25.V.2016, 1 ; Haller park, 26.iv.2016, 20 우우,

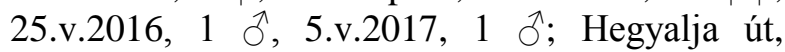

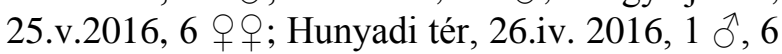

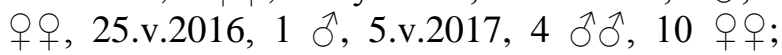
Hủvösvölgy, 25.v.2016, 2 q⿱㇒; Karolina út,

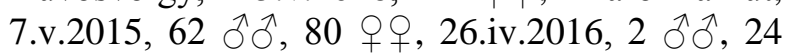
웅, 25.v.2016, 1 ठ, 5.v.2017, 1; Keleti Pályaudvar, 26.iv. 2016, 2 ઈิ๊, 2 ㅇ; Ludovika tér, 5.v.2017, 1 क; Margit-sziget, 26.iv.2016, 3 đึ̄ 35 우우; Mátyás tér, 26.iv.2016, 2 우우, 5.v.2017, 1 ๆ; Normafa, 25.v.2016, 2 우; Rácz Aladár út, 25.v.2016, 4 ठิ $\widehat{0}, 15$ 우; Rákóczi tér,

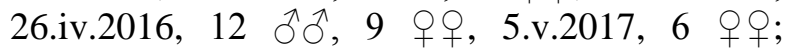
Róbert Károly körút, 26.iv.2016, 6 + , 5.v.2017, 9 우; Széchenyi-hegy, 25.v.2016, 7 우우; Törökbálint, 25.v.2016, 1 市; Vérmezö, 25.v.2016,

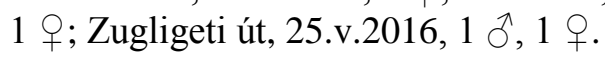

Altogether, 20 males and 183 females were collected in April, 206 males and 304 females in May and only one female was found in June. For doubtfully identified (presumably $P$. assimilis) specimens, the corresponding values were 68 nymphs, 119 male and 58 female individuals in April and 5 nymphs, 72 male and 32 female individuals in May.

Other Psallus species in the same samples were P. wagneri Ossiannilsson, 1953 (Botanical Garden Buda, 26.iv.2016, 2 §ิં; Csillebérc,

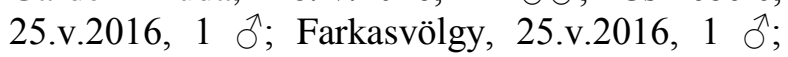
Hegyalja út, 25.v.2016, 1 đ), P. perrisi Mulsant \& Rey, 1852 (Botanical Garden Buda, 26.iv.2016, 1 ऊ; Csillebérc, 25.v.2016, 1 đ) and individuals representing either $P$. perrisi or $P$. wagneri, (Botanical Garden Buda, 26.iv.2016, 3 우우; Csillebérc, 25.v.2016, 3 qq ; Karolina út, 7.v. 2015, 1 +; Széchenyi-hegy, 25.v.2016, 1 +) but doubtfully associated with either of these two species.

\section{DISCUSSION}

Distribution. Psallus assimilis was first reported from Great Britain (Stichel 1956-1958, Auke- 
ma 1981). Later it was also found in Germany (Rieger 1972), Luxembourg (Reichling 1984), the Netherlands (Aukema 1986), France (Matocq 1989), Poland (Gorczyca 1990), Austria (Melber et al. 1991), Italy (Bacchi \& Rizzotti Vlach 1994), Serbia (Protic 1999), Belgium and Sweden (Kerzhner \& Josifov 1999), Czech Republic (Kment \& Bryja 2001), Slovakia (Bryja \& Kment 2002), Switzerland (Wyniger \& Burckhardt 2003) and Spain (Pagola-Carte et al. 2006). Psallus assimilis was also mentioned from Finland (Stichel 1956-1958) and Denmark (Skipper 2017), though its presence in these countries still needs to be confirmed (Endrestøl \& Ødegaard 2011).

Habitat and bionomics. Psallus assimilis prefers woody habitats (forests, forest edges and woodlands) and lives on Acer campestre (Rabitsch 2008, Friess 2011, Heckmann \& Blöch linger 2011). It is univoltine and overwinters in the egg stage (Wachmann et al. 2004, Rabitsch 2008) on young twigs of the host plant (Aukema $\&$ Hermes 2009). It is zoophytophagous, reported as a predator of various insects including psyllids (Jerinić-Prodanović \& Protić 2013). In the studied areas, adults are active from the end of April to the beginning of June.

Adult. The general appearance of the adults is shown in Figs. 1a-b. Length of body 3.3-3.9 mm. The Antenna yellowish, segment I with two setae. Corium, embolium and cuneus reddish orange, membrane brown. Tibiae yellow, with brown spines arising from brown spots. Tarsus yellowish, third tarsal segment dark (Figs. 1a-b). Ventral surface of metafemora with longitudinally arranged brown spots (Figs. 1c-d).

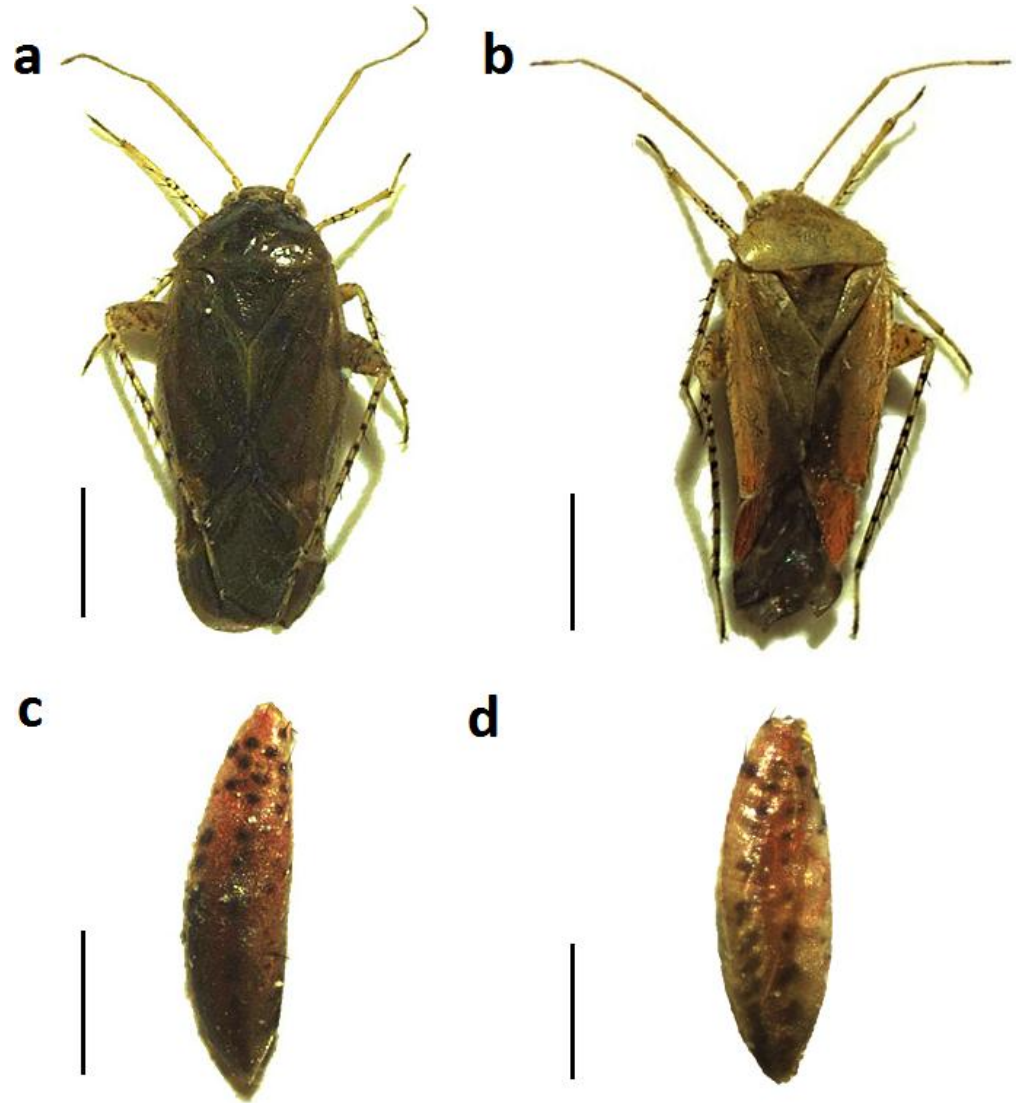

Figure 1. Psallus assimilis Stichel, 1956. $a=$ male, dorsal view; $b=$ female, dorsal view; $c=$ male, ventral surface of metafemur; $\mathrm{d}=$ female, ventral surface of metafemur. Scale bars $=1 \mathrm{~mm}$ (Fig. 1a-b), $0.5 \mathrm{~mm}$ (Fig. 1c-d). (Photo: Dávid Korányi.) 


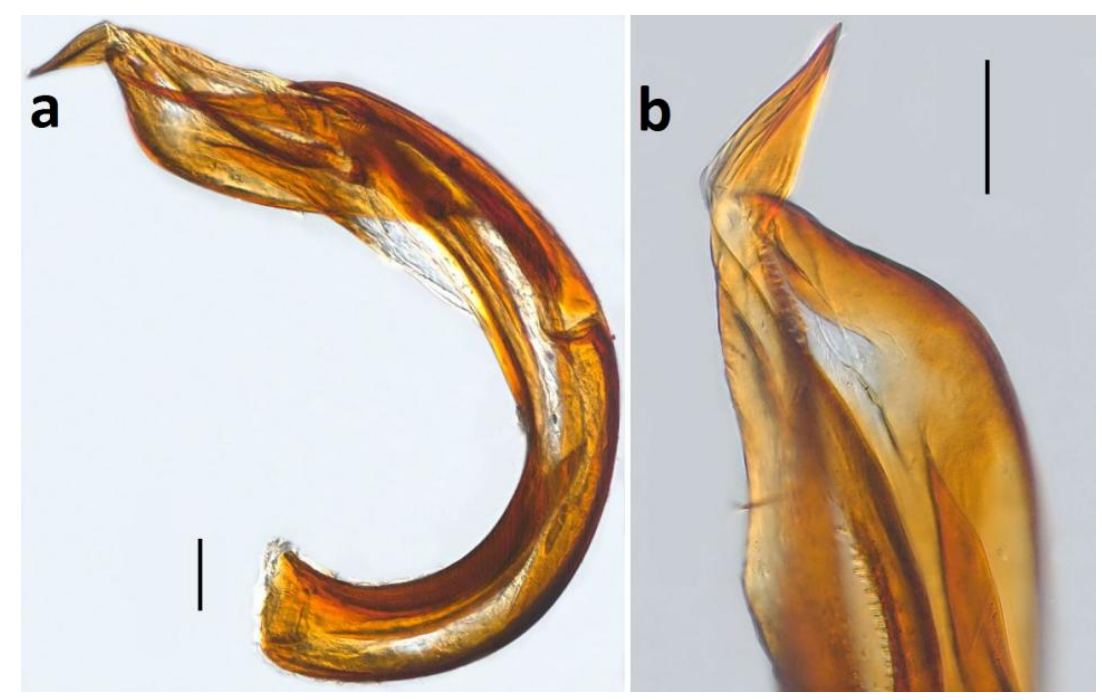

Figure 2. Cleared and dissected vesica of Psallus assimilis Stichel, 1956. a = ventral view; $\mathrm{b}=$ apex, magnified; scale bars $=0.1 \mathrm{~mm}$. (Photo: Dávid Korányi.)

Male. Body elongate, head, scutellum and clavus orange brown, pronotum bright brown (Fig. 1a). Femora brownish, with yellowish apical part (Fig. 1c). Vesica C-shaped, basal lateral process long, straight, slightly surpassing apical margin of secondary gonopore, apical lateral process straight and widened (Figs. 2a-b).

Female. Body roundish, head, pronotum, scutellum and clavus yellowish red (Fig. 1b). Femora yellowish, with brown basal part (Fig. 1d).

The large number of individuals of $P$. assimilis collected during the present study suggests that this species is either autochthonous in Hungary (but has not been found yet due to the lack of intensive collecting from maple trees) or it is a recent invader which has already successfully established and it is present since several years. We have reexamined the Psallus spp. specimens in the Hemiptera Collection of HNHM and did not find any further specimens of $P$. assimilis. Since other congeners ( $P$. perrisi, $P$. wagneri) were found in low abundance, $P$. assimilis can be considered as the dominant (most abundant) Psallus species in the canopy of Acer campestre in the studied region. Furthermore, based on our results, this species was one of the most common true bug species not only in urban forests (e.g. Csillebérc, Hüvösvölgy, Széchenyi-hegy), but also in urban areas bounded by artificial surfaces (e.g. Alkotás street, Karolina street, Rákóczi tér). Besides of the pollen of its host plant, aphids (Periphyllus spp., Drepanosiphum spp.) that occurred in large numbers in the canopy of A. campestre trees could serve as food for the species at these locations.

With the present new record, the number of Psallus species recorded from Hungary is brought to 24; accordingly, Psallus is the most speciesrich true bug genera in Hungary.

Acknowledgements - We are grateful to Hannes Günther and Christian Rieger for helping in the identification of the specimens. Special thanks are due to an anonymous reviewer and Dávid Rédei for their help with the Manuscript. This study was financially supported by the National Research, Development and Innovation Office of Hungary (K112743) and the EFOP-3.6.3-VEKOP-16-2017-00008 project. The project is co-financed by the European Union and the European Social Fund.

\section{REFERENCES}

Aukema, B. (1981): A survey of the Dutch species of the subgenus Hylopsallus of Psallus (HemipteraHeteroptera, Miridae). Tijdschrift voor Entomologie, 124(1): 1-25.

AukemA, B. (1986): Psallus (Hylopsallus) assimilis Stichel, 1956 en $P$. (H.) pseudoplatani Reichling, 1984, twee miriden nieuw voor de Nederlandse fauna (Heteroptera: Miridae, Phylinae). Entomologische Berichten, 46: 117-119. 
AukEMA, B. \& HeRMES, D. (2009): Nieuwe en interessante nederlandse wantsen III (Hemiptera: Heteroptera). Nederlandse Faunistische Mededelingen, 31: 53-88.

AukemA, B., RIEGER, C. \& RABITSCH, W. (2013): Catalogue of the Heteroptera of the Palaearctic Region. Volume 6 Supplement. Netherlands Entomological Society, Amsterdam, 629 pp.

BACCHI, I. \& RizzotTI Vlach, M. (1994): Quattro specie del genere Psallus Fieber, 1858 nuove per la fauna italiana (Heteroptera: Miridae). Atti XVII Congresso Nazionale Italiano di Entomologia, Udine, Italia, pp. 191-194.

Buörkman, C., Maisonnasse, A. \& EKLUnd, K. (2009): Biology and performance on different diets of an omnivorous insect predator, Psallus haematodes (Heteroptera: Miridae). Entomologisk Tidskrift, 130(3-4): 145-153.

BRYJA, J. \& KMENT, P. (2002): New and interesting records of plant bugs (Heteroptera, Miridae) from the Czech and Slovak Republic. Klapalekiana, 38: $1-10$.

Endrestøl, A. \& ØdegaARD, F. (2011): Psallus Fieber, 1858 and Parapsallus Wagner, 1952 (Hem.Het., Miridae) in Norway. Norwegian Journal of Entomology, 58(1): 81-92.

FRIESS, T. (2011): Tag der Artenvielfalt-Wanzen (Insecta: Heteroptera) im Botanischen Garten Graz. Mitteilungen des Naturwissenschaftlichen Vereines für Steiermark, 141: 221-233.

GORCZYCA, J. (1990): Asthenarius quercus (Kirschbaum) and four species of Psallus Fieber (subgn. Hylopsallus Wagner) (Heteroptera, Miridae) in Poland. Polskie Pismo Entomologiczne, 60(3-4): 195-203.

GOßNER, M. (2008): Heteroptera (Insecta: Hemiptera) communities in tree crowns of beech, oak and spruce in managed forests: Diversity, seasonality, guild structure, and tree specificity. In. FLOREN, A. \& SCHMIDL, J. (Eds.) Canopy arthropod research in Europe, Bioform entomology, Nuremberg, p. 119143.

Heckmann, R. \& BlÖChlingeR, H. (2011): Die Wanzenfauna (Hemiptera: Heteroptera) des Kantons Thurgau. Teil 1: Dipsocoromorpha, Nepomorpha, Gerromorpha, Leptopodomorpha und Cimicomorpha. Mitteilungen der Thurgauische Naturforschende Gesellschaft, 65: 77-173.
JeriniĆ-Prodanović, D. \& Protić, L. (2013): True bugs (Hemiptera, Heteroptera) as psyllid predators (Hemiptera, Psylloidea). ZooKeys, 319: 169-189. doi: $\underline{10.3897 / \text { zookeys.319.4316 }}$

KERZHNER, I.M. \& JOSIFOV, M. (1999): Miridae. In. Aukema, B. \& RIEGER, C. (Eds.) Catalogue of the Heteroptera of the Palaearctic Region. Volume 3. Cimicomorpha II. Netherlands Entomological Society, Amsterdam, 402 pp.

KMENT, P. \& BRYJA, J. (2001): New and interesting records of true bugs (Heteroptera) from the Czech Republic. Klapalekiana, 37: 231-248.

KondOROSY, E. (1999): Checklist of the Hungarian bug fauna (Heteroptera). Folia Entomologica Hungarica, 60: 125-152.

Kondorosy, E. (2005): New true bug species in the Hungarian fauna (Heteroptera). Folia Entomologica Hungarica, 66: 17-22.

KondOROSY, E. (2011): Keszthely és környéke poloskafaunájának alapvetése (Heteroptera). [Heteroptera fauna of Keszthely and vicinity] Folia Musei Historico-Naturalis Bakonyiensis, 28: 105-145.

KondOROSY, E. (2012): Invasive alien bug (Heteroptera) species in Hungary. Növényvédelem, 48(3): 97-104. [in Hungarian]

MAtocQ, A. (1989): The presence in France of Psallus (Hylopsallus) pseudoplatani Reichling and confirmation of that of $P$. (H.) assimilis Stichel (Heteroptera, Miridae). Nouvelle Revue d'Entomologie, 6(1): 25-28.

Melber, A., Günther, H. \& RIEGer, C. (1991): Die Wanzenfauna des österreichischen Neusiedlerseegebietes (Insecta, Heteroptera). Wissenschaftliche Arbeiten aus dem Burgenland, 89: 63-192.

PAgOla-CARTE, S., ZABAlegui, I. \& RiBes, J. (2006): Miridae (Hemiptera: Heteroptera) de los Parques Naturales de Aralar e Izki (País Vasco, norte de la Península Ibérica). Heteropterus Revista de Entomología, 6: 105-135.

Protić, L. (1999): Six species of Miridae new to the fauna of Yugoslavia. Acta Entomologica Slovenica, 7: 53-57.

RABITSCH, W. (2008): The times they are a-changin': driving forces of recent additions to the Heteroptera fauna of Austria. In. GROZEVA, S. \& SIMOV, N. (Eds.) Advances in Heteroptera Research. Festschrift in Honour of 80th Anniversary 
of Michail Josifov. Pensoft Publishers, Sofia, p. 309-329.

REICHLING, L. (1984): Hétéroptères du Grand-Duché de Luxembourg. Psallus (Hylopsallus) pseudoplatani n. sp. (Miridae, Phylinae) et especes apparentees. Travaux scientifiques du Musée d'Histoire naturelle, 4(1): 1-18.

RIEGER, C. (1972): Psallus wagneri Oss. und Psallus assimilis Stich. in Süddeutschland (Hem. Miridae). Nachrichtenblatt der Bayerischen Entomologen, 21: $15-16$.

SKIPPER, L. (2017): Checklist of Danish True Bugs (Heteroptera). Version 1.34. Danish Biodiversity Information Facility. Available on-line at: https://doi.org/10.15468/mytdda (accessed $15^{\text {th }}$ December 2017).

STICHEL, W. (1956-1958): Illustrierte Bestimmungstabellen der Wanzen. II. Europa (Hemiptera-Heteroptera Europea). Band 2. W. Stichel, BerlinHermsdorf, p. 170-907.
Wachmann, E., Melber, A. \& Deckert, J. (2004): Wanzen. Band 2: Cimicomorpha mit Microphysidae (Flechtenwanzen) und Miridae (Weichwanzen). Die Tierwelt Deutschlands, Teil 75. Goecke \& Evers, Keltern, p. 255-288.

WAGNER, E. (1967): Wanzen oder Heteroptera II: Cimicomorpha. In. DAHL, M. \& PEUS, F. (Eds.) Die Tierwelt Deutschlands und der angrenzenden Meeresteile, Teil 55. Gustav Fischer Verlag, Jena, p. 1-179.

WYNigER, D. \& BURCKHARDT, D. (2003): The terrestrial bug fauna (Hemiptera, Heteroptera) of Basel (Switzerland) and surroundings. Mitteilungen der Schweizerischen Entomologischen Gesellschaft, 76(1-2): 1-136.

WYNIGER, D. (2004): Taxonomy and phylogeny of the Central European bug genus Psallus (Hemiptera, Miridae) and faunistics of the terrestrial Heteroptera of Basel and surroundings (Hemiptera). $\mathrm{PhD}$ thesis. Universität Basel, Basel, p. 17-18. 